\title{
Front Matter: Volume 9745
}

, "Front Matter: Volume 9745," Proc. SPIE 9745, Organic Photonic Materials and Devices XVIII, 974501 (11 May 2016); doi: 10.1117/12.2239350

SPIE. Event: SPIE OPTO, 2016, San Francisco, California, United States 


\title{
PROCEEDINGS OF SPIE
}

\section{Organic Photonic Materials and Devices XVIII}

\author{
Christopher E. Tabor \\ François Kajzar \\ Toshikuni Kaino \\ Yasuhiro Koike \\ Editors
}

15-17 February 2016

San Francisco, California, United States

Sponsored and Published by

SPIE

Volume 9745

Proceedings of SPIE 0277-786X, V. 9745

SPIE is an international society advancing an interdisciplinary approach to the science and application of light.

Organic Photonic Materials and Devices XVIII, edited by Christopher E. Tabor, François Kajzar, Toshikuni Kaino, Yasuhiro Koike, Proc. of SPIE Vol. 9745, 974501 • @ 2016 SPIE CCC code: $0277-786 X / 16 / \$ 18 \cdot$ doi: $10.1117 / 12.2239350$ 
The papers in this volume were part of the technical conference cited on the cover and title page. Papers were selected and subject to review by the editors and conference program committee. Some conference presentations may not be available for publication. Additional papers and presentation recordings may be available online in the SPIE Digital Library at SPIEDigitallibrary.org.

The papers reflect the work and thoughts of the authors and are published herein as submitted. The publisher is not responsible for the validity of the information or for any outcomes resulting from reliance thereon.

Please use the following format to cite material from these proceedings:

Author(s), "Title of Paper," in Organic Photonic Materials and Devices XVIII, edited by Christopher E. Tabor, François Kajzar, Toshikuni Kaino, Yasuhiro Koike, Proceedings of SPIE Vol. 9745 (SPIE, Bellingham, WA, 2016) Article CID Number.

ISSN: 0277-786X

ISSN: 1996-756X (electronic)

ISBN: 9781628419801

Published by

SPIE

P.O. Box 10, Bellingham, Washington 98227-0010 USA

Telephone +1 3606763290 (Pacific Time) · Fax +1 3606471445

SPIE.org

Copyright @ 2016 , Society of Photo-Optical Instrumentation Engineers.

Copying of material in this book for internal or personal use, or for the internal or personal use of specific clients, beyond the fair use provisions granted by the U.S. Copyright Law is authorized by SPIE subject to payment of copying fees. The Transactional Reporting Service base fee for this volume is $\$ 18.00$ per article (or portion thereof), which should be paid directly to the Copyright Clearance Center (CCC), 222 Rosewood Drive, Danvers, MA 01923. Payment may also be made electronically through CCC Online at copyright.com. Other copying for republication, resale, advertising or promotion, or any form of systematic or multiple reproduction of any material in this book is prohibited except with permission in writing from the publisher. The CCC fee code is 0277-786X/16/\$18.00.

Printed in the United States of America.

Publication of record for individual papers is online in the SPIE Digital Library.

\section{SPIE. DIGITAL}

Paper Numbering: Proceedings of SPIE follow an e-First publication model. A unique citation identifier (CID) number is assigned to each article at the time of publication. Utilization of CIDs allows articles to be fully citable as soon as they are published online, and connects the same identifier to all online and print versions of the publication. SPIE uses a six-digit CID article numbering system structured as follows:

- The first four digits correspond to the SPIE volume number.

- The last two digits indicate publication order within the volume using a Base 36 numbering system employing both numerals and letters. These two-number sets start with 00, 01, 02, 03, 04, $05,06,07,08,09,0 A, 0 B \ldots$ OZ, followed by 10-1Z, 20-2Z, etc. The CID Number appears on each page of the manuscript. 


\title{
Contents
}

\author{
$\checkmark$ Authors \\ vii Conference Committee
}

\section{BIOPHOTONICS}

974502 Electro-optic enhancing interfacial buffer layers for nonlinear optic polymers (Invited Paper) [9745-1]

OPTICAL WAVEGUIDES

9745 OD Fabrication of polymer based integrated photonic devices by maskless lithography [9745-12]

MATERIALS I

$9745 \mathrm{OE}$ 3D printing of natural organic materials by photochemistry (Keynote Paper) [9745-13]

$9745 \mathrm{OH}$ High-conductance low-voltage organic thin film transistor with locally rearranged poly(3-hexylthiophene) domain by current annealing on plastic substrate [9745-19]

9745 Ol Protein-based flexible whispering gallery mode resonators [9745-61]

EO-POLYMER MATERIALS/DEVICES

$97450 Q \quad H y b r i d$ plasmonic/electro-optic polymer modulator [9745-24]

\section{NANOPHOTONICS}

$9745 \mathrm{OR}$ Optimization of electrospinning techniques for the realization of nanofiber plastic lasers (Invited Paper) [9745-25]

9745 OS Control of photon transport properties in nanocomposite nanowires (Invited Paper) [9745-26]

9745 OT Measurement of molecular length of self-assembled monolayer probed by localized surface plasmon resonance [9745-27] 
9745 OW Fully solution processed organic light-emitting electrochemical cells (OLEC) with inkjet printed micro-lenses for disposable lab-on-chip applications at ambient conditions [9745-30]

NONLINEAR OPTICS

974510 Quantum calculation of the second-order hyperpolarizability of chiral molecules in the "one-electron" model (Invited Paper) [9745-34]

ORGANIC/INORGANIC HYBRIDS I

974515 Printed optically transparent graphene cellulose electrodes [9745-39]

\section{ORGANIC/INORGANIC HYBRIDS II}

974517 Organic-inorganic composites for THz device fabrication (Invited Paper) [9745-41]

974519 Photovoltaic and optical properties of perovskite thin films fabricated using Marangoni flow assisted electrospraying [9745-43]

\section{POSTER SESSION}

9745 1E High efficiency polymer light emitting diodes using ternary electron injection layers [9745-48]

974511 Carrier injection and recombination processes in perovskite $\mathrm{CH}_{3} \mathrm{NH}_{3} \mathrm{Pbl}_{3}$ solar cells studied by electroluminescence spectroscopy [9745-52]

$97451 \mathrm{~J} \quad$ Growth directions of $\mathrm{C}_{8}$-BTBT thin films during drop-casting [9745-53]

$97451 \mathrm{~K} \quad$ Effect of UV irradiation on adsorption/desorption of oxygen and water on carbon nanotubes [9745-54]

$97451 Q \quad$ Photonic applications based on biological/inorganic nano hybrids [9745-62] 


\section{Authors}

Numbers in the index correspond to the last two digits of the six-digit citation identifier (CID) article numbering system used in Proceedings of SPIE. The first four digits reflect the volume number. Base 36 numbering is employed for the last two digits and indicates the order of articles within the volume. Numbers start with 00, 01, 02, 03, 04, 05, 06, 07, 08, 09, OA, OB...0Z, followed by 10-1Z, 20-2Z, etc.

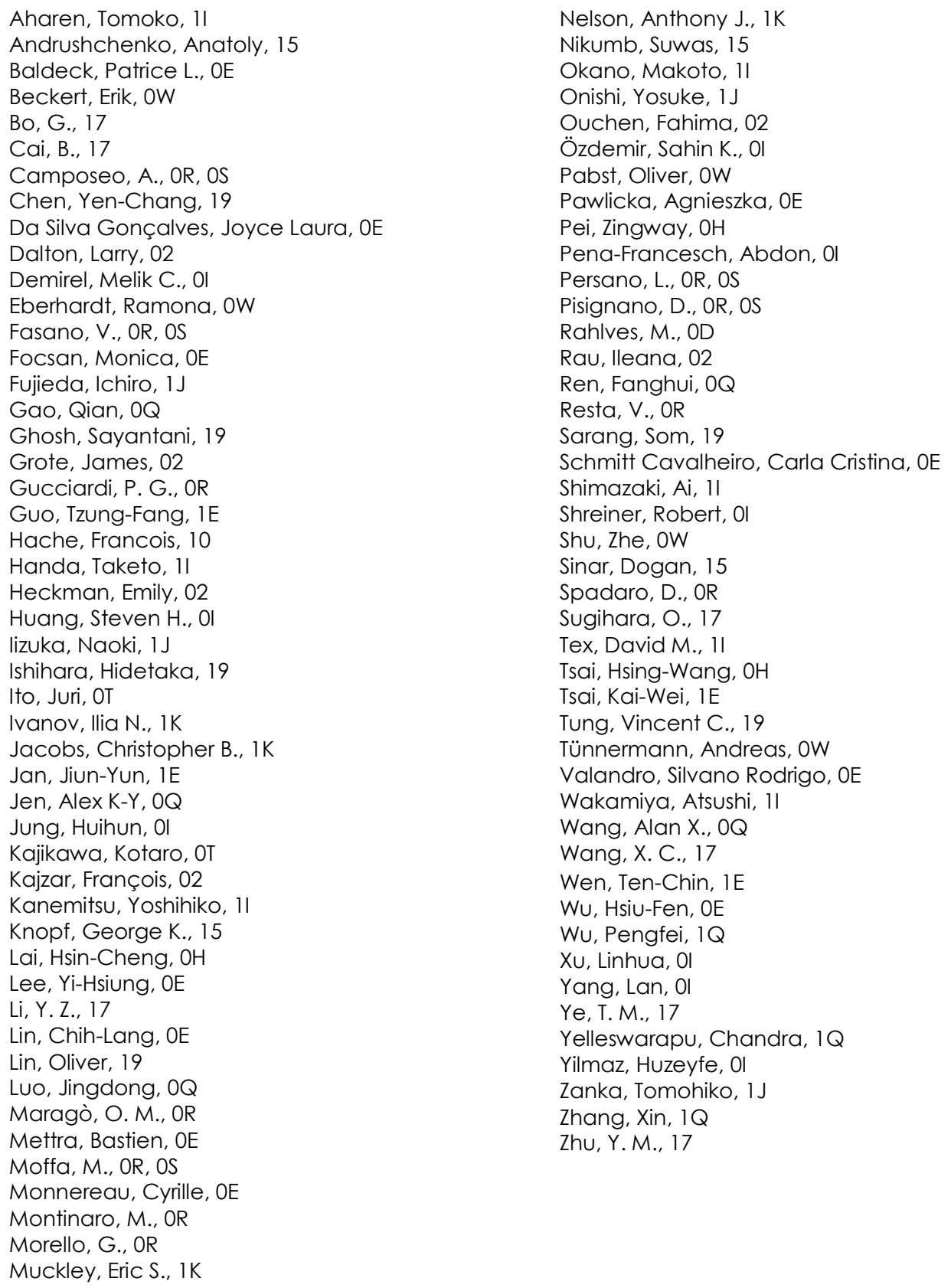


Proc. of SPIE Vol. $9745974501-6$

Downloaded From: https://www.spiedigitallibrary.org/conference-proceedings-of-spie on 26 Apr 2023 Terms of Use: https://www.spiedigitallibrary.org/terms-of-use 


\section{Conference Committee}

Symposium Chairs

Jean-Emmanuel Broquin, IMEP-LAHC (France)

Shibin Jiang, AdValve Photonics, Inc. (United States)

Symposium Co-chairs

David L. Andrews, University of East Anglia (United Kingdom)

Alexei L. Glebov, OptiGrate Corporation (United States)

Program Track Chair

James G. Grote, Air Force Research Laboratory (United States)

Conference Chairs

Christopher E. Tabor, Air Force Research Laboratory (United States)

François Kajzar, University Politehnica of Bucharest (Romania)

Toshikuni Kaino, Tohoku University (Japan)

Yasuhiro Koike, Keio University (Japan)

\section{Conference Program Committee}

Chantal Andraud, Ecole Normale Supérieure de Lyon (France)

Werner J. Blau, Trinity College Dublin (Ireland)

Andreas Bräuer, Fraunhofer-Institut für Angewandte Optik und Feinmechanik (Germany)

Fabrice Charra, Commissariat à l'Énergie Atomique (France)

Beata J. Derkowska-Zielinska, Nicolaus Copernicus University (Poland)

Raluca Dinu, GigOptix, Inc. (United States)

Manfred Eich, Technische Universität Hamburg-Harburg (Germany)

Alain F. Fort, Institut de Physique et Chimie des Matériaux de Strasbourg (France)

James G. Grote, Air Force Research Laboratory (United States)

F. Kenneth Hopkins, Air Force Research Laboratory (United States)

Alex K. Y. Jen, University of Washington (United States)

Michael H. C. Jin, Johns Hopkins University Applied Physics Lab., LLC (United States)

Eunkyoung Kim, Yonsei University (Korea, Republic of)

Jang-Joo Kim, Seoul National University (Korea, Republic of)

Nakjoong Kim, Hanyang University (Korea, Republic of)

Isabelle Ledoux-Rak, Ecole Normale Supérieure de Cachan (France)

Charles Y. C. Lee, Air Force Office of Scientific Research (United States)

Kwang-Sup Lee, Hannam University (Korea, Republic of)

Misoon Y. Mah, Asian Office of Aerospace Research and Development (Japan) 
Seth R. Marder, Georgia Institute of Technology (United States)

Antoni C. Mitus, Wroclaw University of Technology (Poland)

Jaroslaw Mysliwiec, Wroclaw University of Technology (Poland)

Robert L. Nelson, Air Force Research Laboratory (United States)

Robert A. Norwood, College of Optical Sciences, The University of Arizona (United States)

Jean-Michel Nunzi, Queen's University (Canada)

Shuji Okada, Yamagata University (Japan)

Akira Otomo, National Institute of Information and Communications Technology (Japan)

Ileana Rau, University Politehnica of Bucharest (Romania)

Niyazi Serdar Sariciftci, Johannes Kepler Universität Linz (Austria)

Devanand K. Shenoy, Defense Advanced Research Projects Agency (United States)

Kenneth D. Singer, Case Western Reserve University (United States)

Attila A. Szep, Air Force Research Laboratory (United States)

Rebecca E. Taylor, Lockheed Martin Space Systems Company (United States)

Jeong-Weon Wu, Ewha Womans University (Korea, Republic of)

Shiyoshi Yokoyama, Kyushu University (Japan)

Roberto Zamboni, Istituto per la Sintesi Organica e la Fotoreattività (Italy)

\section{Session Chairs}

1 Biophotonics

François Kajzar, University Politehnica of Bucharest (Romania)

2 Solar Cells

Ileana Rau, University Politehnica of Bucharest (Romania)

3 Optical Waveguides

Bernard Kippelen, Georgia Institute of Technology (United States)

4 Materials I

Yasuhiro Koike, Keio University (Japan)

5 Materials II

Patrice L. Baldeck, Ecole Normale Supérieure de Lyon (France)

6 EO-Polymer Materials/Devices

Toshikuni Kaino, Tohoku University (Japan)

7 Nanophotonics

Lingdong Luo, University of Washington (United States)

8 OLEDS

Timothy J. White, Air Force Research Laboratory (United States) 
9 Nonlinear Optics

Ifor D. W. Samuel, University of Saint Andrews (United Kingdom)

10 Organic/Inorganic Hybrids I

Christopher E. Tabor, Air Force Research Laboratory (United States)

11 Organic/Inorganic Hybrids II

André-Jean Attias, Université Pierre et Marie Curie (France) 
Proc. of SPIE Vol. $9745974501-10$

Downloaded From: https://www.spiedigitallibrary.org/conference-proceedings-of-spie on 26 Apr 2023 Terms of Use: https://www.spiedigitallibrary.org/terms-of-use 